\title{
THE INHIBITION AND ADSORPTION PROPERTIES OF DTPMP - TSC ON STAINLESS STEEL IN ACIDIC MEDIUM
}

\author{
P. Selvakumar ${ }^{1, *}$, B. Balanaga karthik ${ }^{2}$, C. Thangavelu ${ }^{3}$ \\ ${ }^{1,{ }^{*}}$ Department of Chemistry, Chettinad College of Engineering and Technology, Karur, TN, India. \\ ppselva@gmail.com \\ ${ }^{2}$ Department of Chemistry, KCG College of Technology, Chennai, TN, India. \\ Karthik8210@gmail.com \\ ${ }^{3}$ Department of Chemistry, Periyar EVR College (Autonomous), Tiruchirappalli, TN, India. \\ drkctv@gmail.com
}

\section{ABSTRACT}

The inhibition effect of diethylenetriamine penta(methylene phosphonic acid) (DTPMP) and Trisodium Citrate (TSC) on the corrosion behavior of stainless steel in $0.5 \mathrm{M} \mathrm{H}_{2} \mathrm{SO}_{4}$ solution was investigated by using weight loss method. The combined corrosion inhibition efficiency offered 200 ppm of DTPMP and $150 \mathrm{ppm}$ of TSC was $95 \%$. Polarization study showed that the inhibitors inhibit stainless steel corrosion through mixed mode and electrochemical impedance spectroscopy (EIS) results confirm the adsorption of the inhibitors at stainless steel/acid interface. The adsorption of DTPMP and TSC onto the stainless steel surface was found to follow Langmuir adsorption isotherm modes. Negative values of $\left(\Delta G_{a d s}\right)$ in the acid media ensured the spontaneity of the adsorption process. The nature of the protective film formed on the metal surface has been analyzed by FTIR spectra, SEM and AFM analysis. The activation energy $\left(E_{a}\right)$, free energy change $\left(\Delta \mathrm{G}_{\mathrm{ads}}\right)$, enthalpy change $\left(\Delta \mathrm{H}_{\mathrm{ads}}\right)$ and entropy change $\left(\Delta \mathrm{S}_{\mathrm{ads}}\right)$ were calculated to understand the corrosion inhibition mechanism.

\section{Keywords}

Corrosion inhibition; Stainless steel; Polarization; Adsorption isotherm; FTIR; SEM; AFM

\section{Academic Discipline And Sub-Disciplines}

Chemistry / Electrochemistry

\section{SUBJECT CLASSIFICATION}

Corrosion

\section{TYPE (METHOD/APPROACH)}

Experimental study

\section{Council for Innovative Research}

Peer Review Research Publishing System

Journal: Journal of Advances in Chemistry

Vol. 6, No. 1

editor@cirworld.com

www.cirworld.com 


\section{INTRODUCTION}

Stainless steel has found very wide application both in modern chemical industries and other places [1]. Stainless steel due to its high strength workability and high corrosion resistance is used in various scientific and engineering applications like chemical and pharmaceutical industries [2-3], desalination plants [3], food beverage industry [4], petrochemical industry [5-7], oil and water pipe line [8], ship naval structures [9-10], water supply and architectural applications. Inhibitors are often added to chemical cleaning and pickling process in dilute acids at moderate temperatures. Inhibitors must be stable and effective even under severe conditions in hot concentrated acid [11]. Inhibitors are used during acid treatment of scaled parts in multistage flash (MSF) desalination plants [12]. The adsorption inhibition is related to the presence of heteroatoms such as nitrogen, oxygen, phosphorous and sulfur and long carbon chain length as well as triple bond or aromatic ring in their molecular structure. Generally a stronger co-ordination bond cause higher inhibition efficiency (IE) [13].

\section{MATERIALS AND METHODS}

\subsection{Preparation of working electrode}

Grade 304 Stainless steel strips were cut into $4 \mathrm{~cm} \times 1 \mathrm{~cm} \times 0.2 \mathrm{~cm}$ having the following compositions $(\mathrm{C}-0.021 \%$, Si $0.888 \%, \mathrm{Mn}-1.42 \%, \mathrm{P}-0.0177 \%, \mathrm{~S}-0.0268 \%, \mathrm{Cr}-18.20 \%, \mathrm{Mo}-0.0373 \%, \mathrm{Ni}-9.43 \%, \mathrm{Cu}-0.507 \%, \mathrm{~V}-0.1 \%$, and $\mathrm{Fe}-69.36 \%$ ) were used for weight-loss studies, while coupons of size $1 \mathrm{~cm}^{2}$ were used for electrochemical studies and SEM analysis. The stainless steel strips were cut and polished to mirror finish by table grinding wheels and degreased with Trichloroethylene.

\subsection{Preparation of $0.5 \mathrm{M} \mathrm{H}_{2} \mathrm{SO}_{4}$}

$0.5 \mathrm{M} \mathrm{H}_{2} \mathrm{SO}_{4}$ solution was prepared by diluting $27.8 \mathrm{ml}$ of $18 \mathrm{M} \mathrm{AR}$-Grade $\mathrm{H}_{2} \mathrm{SO}_{4}$ to $1000 \mathrm{ml}$ using double distilled water.

\subsection{Preparation of diethylenetriamine penta(methylene phosphonic acid)}

$1 \mathrm{~g}$ of diethylenetriamine penta(methylene phosphonic acid) (DTPMP) was dissolved in double distilled water and made up to $100 \mathrm{ml}$ in a standard measuring flask. $1 \mathrm{ml}$ of this solution was diluted to $100 \mathrm{ml}$ to get 100 ppm of DTPMP. The structure of DTPMP is given in figure 1.<smiles>O=P(O)(O)CN(CCN(CP(=O)(O)O)CP(=O)(O)O)CCN(CP(=O)(O)O)CP(=O)(O)O</smiles>

Figure 1. Structure of DTPMP

\subsection{Preparation Trisodium citrate solution}

$1 \mathrm{~g}$ of Trisodium Citrate was dissolved in double distilled water and made up to $100 \mathrm{ml}$ in a standard measuring flask. $1 \mathrm{ml}$ of this solution was diluted to $100 \mathrm{ml}$ to get $100 \mathrm{ppm}$ of trisodium citrate. The structure of TSC is given in figure 2 .<smiles>[NH3+][OH+]C(=O)CC(O)(CC(=O)[OH2+])C(=O)[OH2+]</smiles>

Figure 2. Structure of TSC

\subsection{Weight Loss Method}

The weight loss method was carried out on the pre-weighed stainless steel specimens of regular form of dimension $4 \mathrm{~cm} \mathrm{x}$ $1 \mathrm{~cm} \times 0.2 \mathrm{~cm}$ in $100 \mathrm{ml}$ of $0.5 \mathrm{M} \mathrm{H}_{2} \mathrm{SO}_{4}$ solution absence and presence of different concentrations of inhibitor at four different temperatures viz, 303, 313, 313 and $333 \mathrm{~K}$ to study the anticorrosion properties. The specimens were immersed for about 6 hours in test solutions. After the immersion period, the specimens were removed from test solutions carefully, washed with distilled water, dried and again weighed in order to calculate the surface coverage, inhibition efficiency, and corrosion rate using following equations [14].

$$
\begin{aligned}
& \text { Surface coverage }(\theta)=\frac{w_{0}-w_{\mathrm{L}}}{W_{0}} \\
& \text { IE }(\%)=\frac{w_{0}-W_{\mathrm{L}}}{W_{0}} \times 100
\end{aligned}
$$

Where $W_{\circ}$ and $W_{i}$ are the weight loss in the absence and presence of inhibitor, respectively, and 


$$
\mathrm{CR}=\frac{534 X \text { Weight lossin }(\mathrm{mg})}{D A T} \mathrm{mpy}
$$

$D$ - Density of the specimen, A - Area of the specimen in square inches, T - Time in hours.

\subsection{Electrochemical methods}

Electrochemical measurements were performed using a $\mathrm{CHI}$ electrochemical analyzer model 760D instrument with $\mathrm{CHI}$ 760D operating software. A three-electrode electrochemical setup was used. A working stainless steel electrode embedded in Teflon holder was dipped in test solution. A saturated calomel electrode (SCE) and a platinum electrode were used and the reference and counter-electrode respectively. In the case of polarization and electrochemical impedance spectroscopy, prior to each measurement a stabilization period of $30 \mathrm{~min}$ was allowed to establish a steadystate open circuit potential $(\mathrm{OCP}) \pm 200 \mathrm{mv}$ ranges a sweep rate of $2 \mathrm{mV} / \mathrm{s}$. The electrochemical impedance spectroscopy measurements were carried out in the frequency range from $100 \mathrm{kHz}$ to $0.1 \mathrm{~Hz}$ with a signal amplitude perturbation of 5 $\mathrm{mV}$. The double-layer capacitance $\left(\mathrm{C}_{\mathrm{dl}}\right)$ and charge-transfer resistance $\left(\mathrm{R}_{\mathrm{ct}}\right)$ were calculated from Nyquist plots as described elsewhere [15].

\subsection{Surface Morphological studies}

\subsubsection{FT-IR Analysis}

FT-IR spectra were recorded with a frequency ranging 4000 to $400 \mathrm{~cm}^{-1}$ for the inhibitor as well as the inhibitor adsorbed on stainless steel in $0.5 \mathrm{M} \mathrm{H}_{2} \mathrm{SO}_{4}$ solution using FT-IR ATR attachment technique.

\subsubsection{SEM Analysis}

Surface analysis was carried out using scanning electron microscope (SEM). The stainless steel specimens were immersed in $0.5 \mathrm{M} \mathrm{H}_{2} \mathrm{SO}_{4}$ solution without and with inhibitor for about 6 hours. After 6 hours, immersed specimens were drawn from the test solution, cleaned with double distilled water and dried at room temperature. A SEM experiment was performed by using a model JSM 6390 scanning electron microscope.

\subsubsection{AFM Analysis}

The stainless steel specimens immersed in various test solutions for 6 hours were taken out, rinsed with double distilled water, dried and subjected to the surface examination. The surface morphology measurements of the stainless steel surface was analyzed using Park XE-100 atomic force microscopy (AFM)

\section{RESULTS AND DISCUSSION}

\subsection{Weight loss study}

The Weight loss values of stainless steel specimens in both acid media without and with different concentrations of the inhibitors are determined at three various temperatures viz., 303, 313, 323 and $333 \mathrm{~K}$. Inhibition Efficiencies were calculated from the weight loss of stainless steel in $0.5 \mathrm{M} \mathrm{H}_{2} \mathrm{SO}_{4}$ in different concentrations of inhibitor. For example 200 ppm of DTPMP has $53 \%$ inhibition efficiency and 150 ppm of TSC has only $48 \%$ inhibition efficiency. When DTPMP is combined with TSC, it is found that inhibition efficiency increases up to $95 \%$. The results indicate that the inhibitor produces a significant anticorrosive effect. Similar observations have been reported for corrosion inhibition [16]. The corrosion rates and inhibition efficiencies of stainless steel in $0.5 \mathrm{M} \mathrm{H}_{2} \mathrm{SO}_{4}$ solution presence and absence of inhibitors are listed in table 1.

Table.1 Corrosion rates \& inhibition efficiencies of Stainless steel in $0.5 \mathrm{M} \mathrm{H}_{2} \mathrm{SO}_{4}$ solution in presence and absence of inhibitors obtained by weight loss method at $303 \mathrm{~K}$

\begin{tabular}{|c|c|c|c|c|c|}
\hline Medium & $\begin{array}{l}\text { Conc. Of } \\
\text { DTPMP } \\
\text { (ppm) }\end{array}$ & $\begin{array}{l}\text { Conc. Of } \\
\text { TSC (ppm) }\end{array}$ & $\begin{array}{c}\text { Corrosion Rate } \\
\text { (mpy) }\end{array}$ & IE (\%) & $\begin{array}{c}\text { Surface } \\
\text { coverage }(\theta)\end{array}$ \\
\hline \multirow{10}{*}{$\begin{array}{l}0.5 \mathrm{M} \\
\mathrm{H}_{2} \mathrm{SO}_{4}\end{array}$} & 0 & 0 & 41.56 & -- & -- \\
\hline & 200 & 0 & 19.40 & 53.33 & 0.5333 \\
\hline & 0 & 150 & 21.61 & 48.00 & 0.4800 \\
\hline & 200 & 25 & 27.43 & 34.00 & 0.3400 \\
\hline & 200 & 50 & 19.40 & 53.33 & 0.5333 \\
\hline & 200 & 75 & 13.30 & 68.00 & 0.6800 \\
\hline & 200 & 100 & 9.42 & 77.33 & 0.7733 \\
\hline & 200 & 125 & 4.99 & 88.00 & 0.8800 \\
\hline & 200 & 150 & 2.22 & 94.67 & 0.9467 \\
\hline & 200 & 175 & 3.33 & 92.00 & 0.9200 \\
\hline
\end{tabular}




\subsection{Potentiodynamic polarization:}

The potentiodynamic polarization curves of Stainless steel immersed in $0.5 \mathrm{M} \mathrm{H}_{2} \mathrm{SO}_{4}$ solution absence and presence of inhibitors is shown in figure 3.

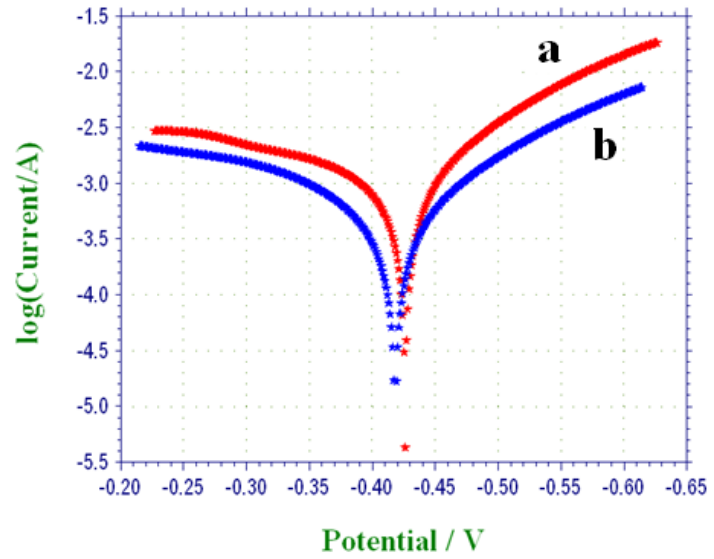

Figure 3. Potentiodynamic polarization curves for stainless steel in $0.5 \mathrm{M} \mathrm{H}_{2} \mathrm{SO}_{4}$ solution in (a) absence (b) presence of inhibitors.

The corrosion parameters of Stainless steel is immersed in various test solution obtained by polarization study are given in table 2. When Stainless steel is immersed in $0.5 \mathrm{M} \mathrm{H}_{2} \mathrm{SO}_{4}$, the corrosion current $\mathrm{I}_{\text {corr }}$ is $15.44 \times 10^{-4} \mathrm{~A} / \mathrm{cm}^{2}$. When $200 \mathrm{ppm}$ of DTPMP and 150 TSC are added, it decreases to $6.706 \times 10^{-4} \mathrm{~A} / \mathrm{cm}^{2}$. The significant reduction in corrosion current indicates a decrease in corrosion rate in the presence of the inhibitor. It shows that addition of inhibitor molecules anodic dissolution of stainless steel and also retards the hydrogen evolution reaction. This effect is attributed to the adsorption of the inhibitor on the metal surface. It is also clear that there is a shift towards anodic region in the values of corrosion potential $E_{\text {corr. }}$ Generally it is reported that a change in $E_{\text {corr }}$ values of up to $\pm 85 \mathrm{mV}$ can be attributed to a mixed mode of inhibition action. [17-19]. This indicates that a protective film is formed on the metal surface [20-21]. The IE was calculated using the following equation,

$$
\text { IE }(\%)=\frac{I_{\text {corr }}-I_{\text {corrm }}(\text { inh) }}{I_{\text {corr }}} \times 100
$$

Where $I_{\text {corr }}$ and $I_{\text {corr(inh) }}$ are the corrosion current densities absence and presence of inhibitors respectively [22].

Table 2. Electrochemical parameters of stainless steel in $0.5 \mathrm{M} \mathrm{H}_{2} \mathrm{SO}_{4}$ solution obtained by polarization method.

\begin{tabular}{|c|c|c|c|c|c|}
\hline System & $\mathbf{b}_{\mathbf{a}} \mathbf{~} \mathbf{V}$ & $\mathbf{b}_{\mathbf{c}} \mathbf{~} \mathbf{V}$ & $\begin{array}{c}\mathbf{E}_{\text {corr }} \mathbf{~} \mathbf{V} \mathbf{V} \\
\mathbf{S C E}\end{array}$ & $\mathbf{I}_{\text {corr }} \mathbf{A} / \mathbf{c m}^{2}$ & IE \% \\
\hline Blank & 375.9 & 138.5 & -426 & $15.55 \times 10^{-4}$ & ---- \\
\hline $\begin{array}{c}200 \mathrm{ppm} \\
\text { DTPMP } \\
+150 \text { ppm } \\
\text { TSC }\end{array}$ & 249.3 & 144.5 & -418 & $6.706 \times 10^{-4}$ & 56.87 \\
\hline
\end{tabular}

\subsection{Electrochemical impedence spectroscopy}

The EIS technique is one of the most widely used corrosion monitoring techniques. The Nyquist plots for stainless steel in $0.5 \mathrm{M} \mathrm{H}_{2} \mathrm{SO}_{4}$ solution in absence and presence of inhibitors shown in figure 4. 


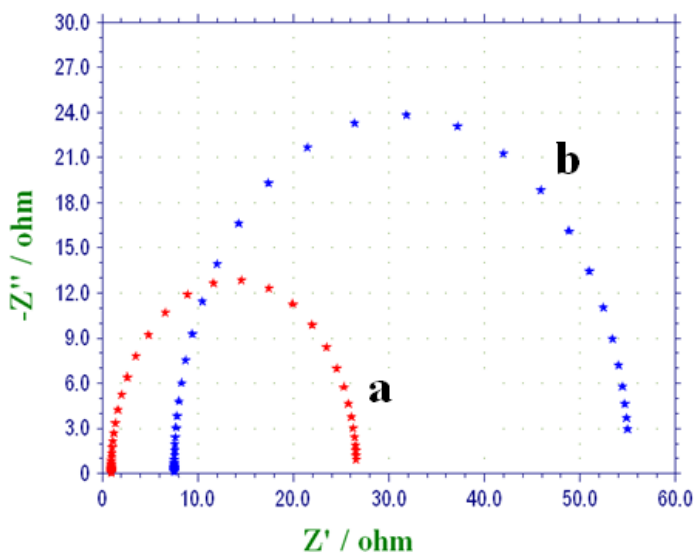

Figure 4. Nyquist plots for stainless steel in $0.5 \mathrm{M} \mathrm{H}_{2} \mathrm{SO}_{4}$ solution in (a) absence and (b) presence of inhibitors.

In the presence of $0.5 \mathrm{M} \mathrm{H}_{2} \mathrm{SO}_{4} \mathrm{R}_{\mathrm{ct}}$ value is $22.52 \Omega \mathrm{cm}^{2}$ and $\mathrm{C}_{\mathrm{dl}}$ value is $6.24 \times 10^{-4} \mu \mathrm{F} \mathrm{cm}^{2}$. When DTPMP \& TSC are added to this solution $R_{\mathrm{ct}}$ value increases to $47.58 \Omega \mathrm{cm}^{2}$ and $C_{\mathrm{dl}}$ value decreases to $1.39 \times 10^{-4} \mu \mathrm{F} \mathrm{cm}{ }^{2}$. This confirms that the formation of a protective film on the metal surface [23-24]. The results of electrochemical studies were in good agreement with the results of gravimetric studies with slight deviations. This is due to the difference in immersion period of stainless steel in the aggressive media [25]. The EIS parameters namely, charge transfer resistance $\left(R_{c t}\right)$ and double layer capacitance $\left(\mathrm{C}_{\mathrm{dl}}\right)$ are given in table 3 .

Table 3. Electrochemical parameters of stainless steel in $0.5 \mathrm{M} \mathrm{H}_{2} \mathrm{SO}_{4}$ solutions are obtained by impedance method.

\begin{tabular}{|c|c|c|}
\hline Systems & $\mathbf{R}_{\mathrm{ct}} \mathbf{\Omega} \mathbf{c m}^{2}$ & $\mathbf{C}_{\mathrm{dI}} \boldsymbol{\mu F ~ \mathbf { ~ m } ^ { 2 }}$ \\
\hline Blank & 22.52 & $6.24 \times 10^{-4}$ \\
\hline $\begin{array}{c}200 \text { ppm DTPMP }+ \\
150 \text { ppm TSC }\end{array}$ & 47.58 & $1.39 \times 10^{-4}$ \\
\hline
\end{tabular}

\subsection{FT-IR Spectra}

The FT-IR spectrum of pure DTPMP is shown in Fig 5 a. The stretching frequency of P-O \& C-N appears at $1059 \mathrm{~cm}^{-1} \&$ $1111 \mathrm{~cm}^{-1}$. The FT-IR spectrum of pure TSC is shown in fig $5 \mathrm{~b}$. The stretching frequency of $\mathrm{C}=\mathrm{O}$ \& $\mathrm{O}-\mathrm{H}$ appears at $1581 \mathrm{~cm}^{-1} \& 3456 \mathrm{~cm}^{-1}$. The FT-IR spectrum of film formed on the stainless steel surface after immersion in the solution containing $200 \mathrm{ppm}$ of DTPMP and $150 \mathrm{ppm}$ of TSC are shown in Fig 5 c. The DTPMP of P-O \& C-N stretching frequencies are shifted from $1059 \mathrm{~cm}^{-1}$ to $945 \mathrm{~cm}^{-1}$ and $1111 \mathrm{~cm}^{-1}$ to $1174 \mathrm{~cm}^{-1}$. The TSC of $\mathrm{C}=\mathrm{O} \& \mathrm{O}-\mathrm{H}$ stretching frequencies are shifted from $1581 \mathrm{~cm}^{-1}$ to $1589 \mathrm{~cm}^{-1}$ and $3456 \mathrm{~cm}^{-1}$ to $3472 \mathrm{~cm}^{-1}$. This suggests that electron cloud density of DTPMP \& TSC atoms is coordinated with $\mathrm{Fe}^{2+}$ on the cathodic sites of the metal surface, resulting in the formation of $\mathrm{Fe}^{2+}$ DTPMP -TSC complex [26-28].
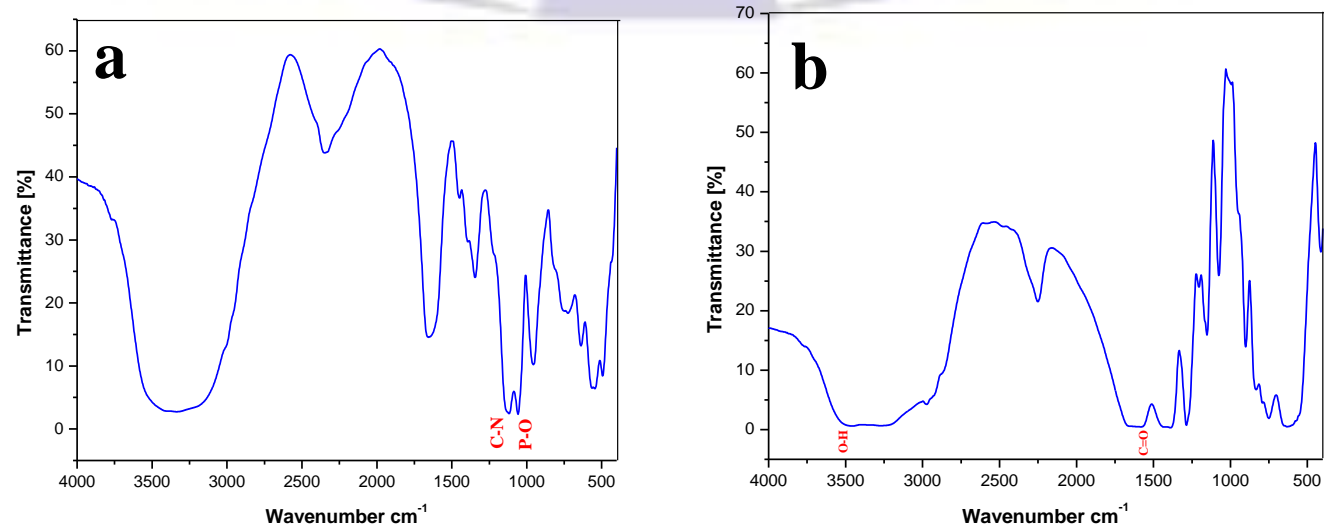


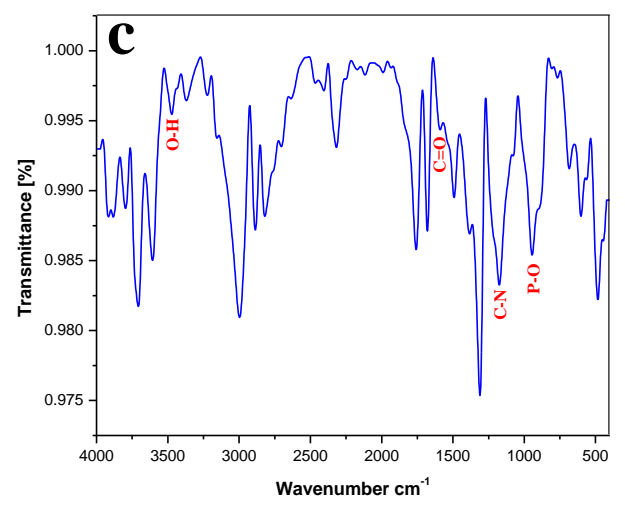

Figure 5. (c) FT-IR spectrum of (a) pure DTPMP (b) Pure TSC

(c) Stainless steel in $0.5 \mathrm{M} \mathrm{H}_{2} \mathrm{SO}_{4}$ solution with DTPMP (200 ppm) and TSC (150 ppm)

\subsection{Thermodynamic Parameters}

Thermodynamic parameters play an important role in studying the inhibitive mechanism. Tables 4 \& 5 show that the calculated values of activation energy $\left(\mathrm{E}_{\mathrm{a}}\right)$, Heat of adsorption $\left(\mathrm{Q}_{\mathrm{ads}}\right)$, enthalpy of adsorption $\left(\Delta \mathrm{H}_{\mathrm{ads}}\right)$, entropy of adsorption $\left(\Delta S_{\text {ads }}\right)$ and free energy of adsorption $\left(\Delta G_{\text {ads }}\right)$ for stainless steel corrosion in $0.5 \mathrm{M} \mathrm{H}_{2} \mathrm{SO}_{4}$ solution presence and absence of inhibitors at $303 \mathrm{~K}$ to $333 \mathrm{~K}$. Energy of activation $\left(E_{a}\right)$ was calculated from the slopes of plots $\log P$ versus $1 / T$ in figure 6 and also calculated from Arrhenius equation [16, 29].

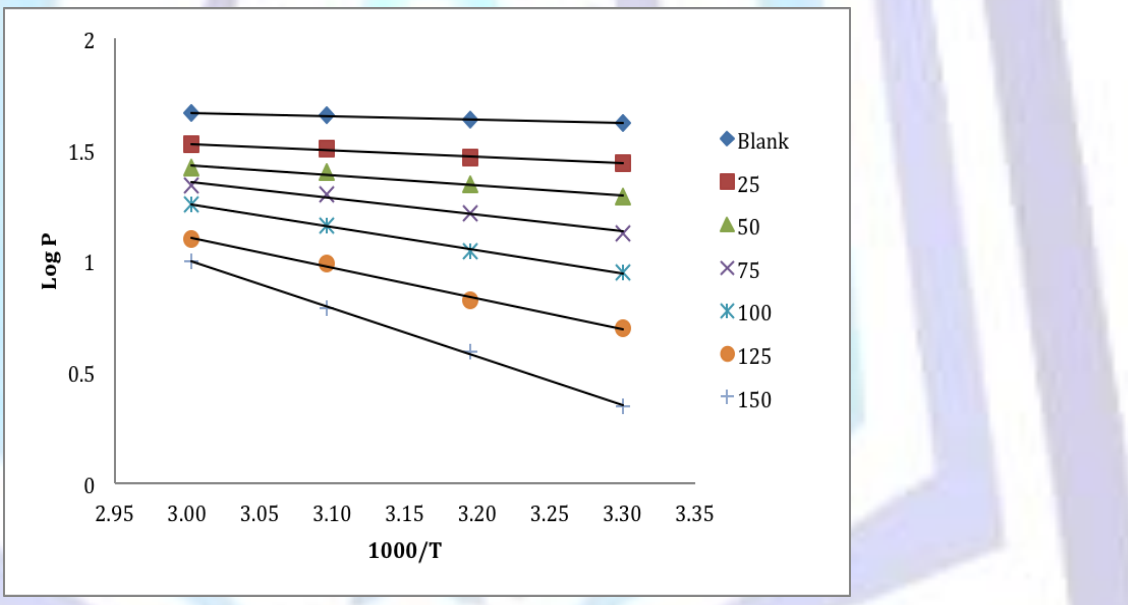

Figure 6. Arrhenius plots for corrosion of Stainless steel in $0.5 \mathrm{M} \mathrm{H}_{2} \mathrm{SO}_{4}$ in absence and presence of different concentration of inhibitors.

$$
\log \frac{P_{2}}{F_{1}}=\frac{E_{2 \pi}}{2303 R}\left[\frac{1}{T 1}-\frac{1}{T 2}\right]
$$

Where $P_{1}$ and $P_{2}$ are the corrosion rates of $T_{1}$ and $T_{2}$ respectively. The $E_{a}$ values for $0.5 \mathrm{M} \mathrm{H}_{2} \mathrm{SO}_{4}$ containing inhibitors are found to be higher than that of without inhibitors. These higher values of $E_{a}$ indicate the physical adsorption of the inhibitors on metal surface [30-31]. The $E_{a}$ values are calculated from the slopes of $-E_{a} / 2.303 R$ Arrhenius plot by using equation (5) are approximately almost similar. The values of heat of adsorption $\left(Q_{a d s}\right)$ are calculated by the following equation [32].

$$
Q_{\text {ads }}=2.303 R\left[\log \left(\frac{\theta_{2}}{1-\theta_{2}}\right)-\log \left(\frac{\theta_{1}}{1-\theta_{1}}\right)\right] X \frac{T_{1} \cdot T_{2}}{T_{2}-T_{1}}
$$

Where $\theta_{1}$ and $\theta_{2}$ surface coverage of inhibitors at temperature $T_{1}$ and $T_{2}$ respectively. The negative values of $\left(Q_{a d s}\right)$ signify that the degree of surface coverage decreased and also inhibition efficiency decreased with rise in temperature [33]. The enthalpy of adsorption $\left(\Delta \mathrm{H}_{\mathrm{ads}}\right)$ and entropy of adsorption $\left(\Delta \mathrm{S}_{\mathrm{ads}}\right)$ are calculated using the following equation [34].

$$
\begin{gathered}
\Delta H=E_{a}-R T \\
\Delta S=\frac{\Delta H-\Delta G}{T} .
\end{gathered}
$$


Table 4. Thermodynamic parameters of $\mathrm{E}_{\mathrm{a}}$ \& $\mathrm{Q}_{\mathrm{ads}}$ for stainless steel in $0.5 \mathrm{M} \mathrm{H}_{2} \mathrm{SO}_{4}$ presence and absence of inhibitors.

\begin{tabular}{|c|c|c|c|c|c|c|c|}
\hline \multirow{2}{*}{$\begin{array}{c}\mathrm{H}_{2} \mathrm{SO}_{4} \\
(\mathrm{M})\end{array}$} & \multirow{2}{*}{$\begin{array}{l}\text { Conc. Of } \\
\text { DTPMP } \\
\text { (ppm) }\end{array}$} & \multirow{2}{*}{$\begin{array}{l}\text { Conc. Of } \\
\text { TSC } \\
\text { (ppm) }\end{array}$} & \multirow{2}{*}{$\begin{array}{c}\mathrm{E}_{\mathrm{a}} \text { (From } \\
\text { equation) } \\
\mathrm{KJ} / \mathrm{mol}\end{array}$} & \multirow{2}{*}{$\begin{array}{c}\mathrm{E}_{\mathrm{a}} \text { (From } \\
\text { Arrhenius plot) } \\
\mathrm{KJ} / \mathrm{mol}\end{array}$} & \multicolumn{3}{|c|}{$\begin{array}{c}Q_{\mathrm{ads}} \\
\mathrm{KJ} / \mathrm{mol}\end{array}$} \\
\hline & & & & & $\begin{array}{l}303- \\
313 K\end{array}$ & $\begin{array}{l}313- \\
323 K\end{array}$ & $\begin{array}{l}323- \\
333 \mathrm{~K}\end{array}$ \\
\hline \multirow{7}{*}{0.5} & 0 & 0 & 2.59 & 2.91 & 0 & 0 & 0 \\
\hline & 200 & 25 & 4.63 & 5.61 & -6.20 & -12.85 & -5.73 \\
\hline & 200 & 50 & 10.53 & 9.71 & -15.62 & -13.33 & -6.09 \\
\hline & 200 & 75 & 16.28 & 16.25 & -21.05 & -22.17 & -11.33 \\
\hline & 200 & 100 & 17.54 & 17.01 & -19.63 & -25.79 & -27.59 \\
\hline & 200 & 125 & 22.65 & 21.23 & -23.29 & -34.33 & -26.81 \\
\hline & 200 & 150 & 35.90 & 35.65 & -44.69 & -38.60 & -50.68 \\
\hline
\end{tabular}

Table 5. Thermodynamic parameters of $\Delta \mathbf{G}_{\text {ads, }} \Delta \mathbf{H}_{\text {ads }} \& \Delta \mathbf{S}_{\text {ads }}$ for stainless steel in $0.5 \mathrm{M} \mathrm{H}_{2} \mathrm{SO}_{4}$ presence and absence of inhibitors.

\begin{tabular}{|c|c|c|c|c|c|c|c|c|}
\hline \multirow{2}{*}{$\begin{array}{c}\mathrm{H}_{2} \mathrm{SO}_{4} \\
(\mathrm{M})\end{array}$} & \multirow{2}{*}{$\begin{array}{l}\text { Conc. Of } \\
\text { DTPMP } \\
\text { (ppm) }\end{array}$} & \multirow[t]{2}{*}{$\begin{array}{l}\text { Conc. } \\
\text { Of TSC } \\
\text { (ppm) }\end{array}$} & \multicolumn{4}{|c|}{$\begin{array}{c}-\Delta \mathbf{G}_{\text {ads }} \\
\mathrm{KJ} / \mathrm{mol}\end{array}$} & \multirow{2}{*}{$\begin{array}{c}-\Delta \mathrm{H} \\
\mathrm{KJ} / \mathrm{mol}\end{array}$} & \multirow{2}{*}{$\begin{array}{c}\Delta \mathrm{S} \\
\mathrm{KJ} / \mathrm{mol}\end{array}$} \\
\hline & & & $303 \mathrm{~K}$ & 313K & 323K & 333K & & \\
\hline \multirow{7}{*}{0.5} & 0 & 0 & -- & -- & -- & -- & 2.7664 & -- \\
\hline & 200 & 25 & 14.66 & 14.94 & 15.00 & 14.83 & 2.7647 & 0.0362 \\
\hline & 200 & 50 & 14.92 & 14.89 & 14.94 & 14.76 & 2.7637 & 0.0360 \\
\hline & 200 & 75 & 15.46 & 15.27 & 15.05 & 14.71 & 2.7603 & 0.0359 \\
\hline & 200 & 100 & 15.93 & 16.01 & 15.69 & 14.87 & 2.7486 & 0.0364 \\
\hline & 200 & 125 & 17.29 & 17.09 & 16.54 & 15.74 & 2.7461 & 0.0390 \\
\hline & 200 & 150 & 19.06 & 18.21 & 17.56 & 16.88 & 2.7245 & 0.0425 \\
\hline
\end{tabular}

The negative values of enthalpy of adsorption $\left(\Delta \mathrm{H}_{\mathrm{ads}}\right)$ imply that adsorption process is exothermic behavior of inhibitor on the metal surface [35]. The difference in the inhibition efficiencies of the two compounds depends on their structures, since both of the molecules are attached to the surface of alloy. The positive values of entropy of adsorption $\left(\Delta S_{\text {ads }}\right)$ confirm that the corrosion process is entropically favorable [36]. The free energy of adsorption $\left(\Delta G_{a d s}\right)$ at different temperatures is calculated from the following equation [37].

$$
\Delta \mathrm{G}=-\mathrm{RT} \ln (55.5 \mathrm{~K})
$$

Where $\mathrm{K}$ is given by

$$
K=\frac{\theta}{c(1-\theta)}
$$

Where $\theta$ is the degree of surface coverage on the metal surface, $C$ is the concentration of inhibitor in ppm, the value of 55.5 is the concentration of water in solution expressed in $\mathrm{mol} / \mathrm{lit}, \mathrm{K}$ is the equilibrium constant and $\mathrm{R}$ is the universal gas constant $8.314 \mathrm{KJ} / \mathrm{mol}$. The negative value of $\left(\Delta \mathrm{G}_{\mathrm{ads}}\right)$ suggests the strong interaction of the inhibitor molecules onto the alloy surface [38-39]. Generally the values of $\left(\Delta \mathrm{G}_{\mathrm{ads}}\right)$ up to $-20 \mathrm{KJ} / \mathrm{mol}$ indicating physisorption, while around $-40 \mathrm{KJ} / \mathrm{mol}$ or higher are associated with chemisorption. It is due to sharing or transferring electrons from the inhibitor molecules to the metal surface to form a co-ordinate bond [40-43].

\subsection{Adsorption Isotherm}

Adsorption isotherm can give information on the metal-inhibitor interaction. The electrochemical process on the metal surface is likely to be closely to the adsorption of the inhibitor [44] and the adsorption is known to depend on the chemical structure of the inhibitors [45-46]. The adsorption of the inhibitors molecules from aqueous solutions can be regarded as 
quasi-substitution process [47] between the organic molecules in the aqueous solution org (aq) and water molecules at the electrode surface, $\mathrm{H}_{2} \mathrm{O}_{(\mathrm{ads})}[48]$.

$$
\operatorname{Org}_{(\mathrm{sol})}+\mathrm{x} \mathrm{H}_{2} \mathrm{O}_{(\mathrm{ads})} \leftrightarrow \operatorname{Org}_{(\mathrm{ads})}+\mathrm{x}_{2} \mathrm{O}
$$

Here $\mathrm{x}$ is the size ratio in the number of water molecules displaced by one molecules of inhibitor. Adsorption isotherms are very important in determining the mechanism of organo-electrochemical reactions. The most frequently used adsorption isotherms are Langmuir, Tempkin and Frumkin with general formula,

$$
f(\theta, x) \exp (-2 a \theta)=K C
$$

Where $f(\theta, x)$ is the configurational factors that depend essentially on the physical model and assumptions underlying the derivation of the isotherm [49].

$$
\frac{C}{\theta}=\frac{1}{K}+C
$$

Where $\mathrm{C}$ is the inhibitor concentration, $\mathrm{K}$ is the adsorption equilibrium constant and $\theta$ is degree of surface coverage. The plot of $C / \theta$ versus $C$ Figure 7 gives a straight line confirming that the adsorption of this inhibitor on metal surface obeys the Langmuir adsorption isotherm [50].

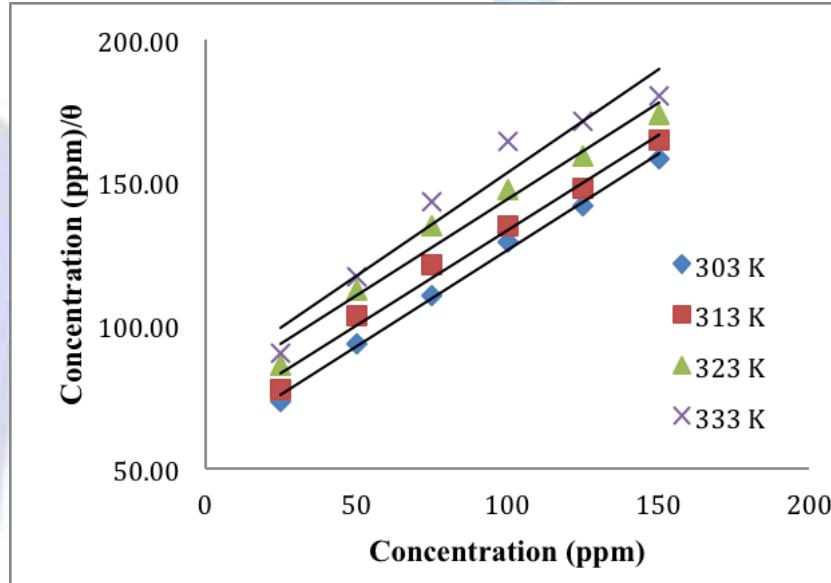

Figure 7. Langmuir adsorption isotherm of DTPMP - TSC on the stainless steel in $0.5 \mathrm{M} \mathrm{H}_{2} \mathrm{SO}_{4}(303-333 \mathrm{~K})$

\subsection{Scanning Electron Microscope}

The surface morphology of stainless steel studied by scanning electron microscopy (SEM) surface was observed after 6 hours immersion of $0.5 \mathrm{M} \mathrm{H}_{2} \mathrm{SO}_{4}$ at $303 \mathrm{~K}$ before and after addition of DTPMP and TSC. Figures 8 a \& $\mathrm{b}$, magnification ( $\mathrm{x}$ $1000, \times 3000$ ) show the polished metal surface of stainless steel before being exposed to the testing environment, it was observed as a uniform surface.

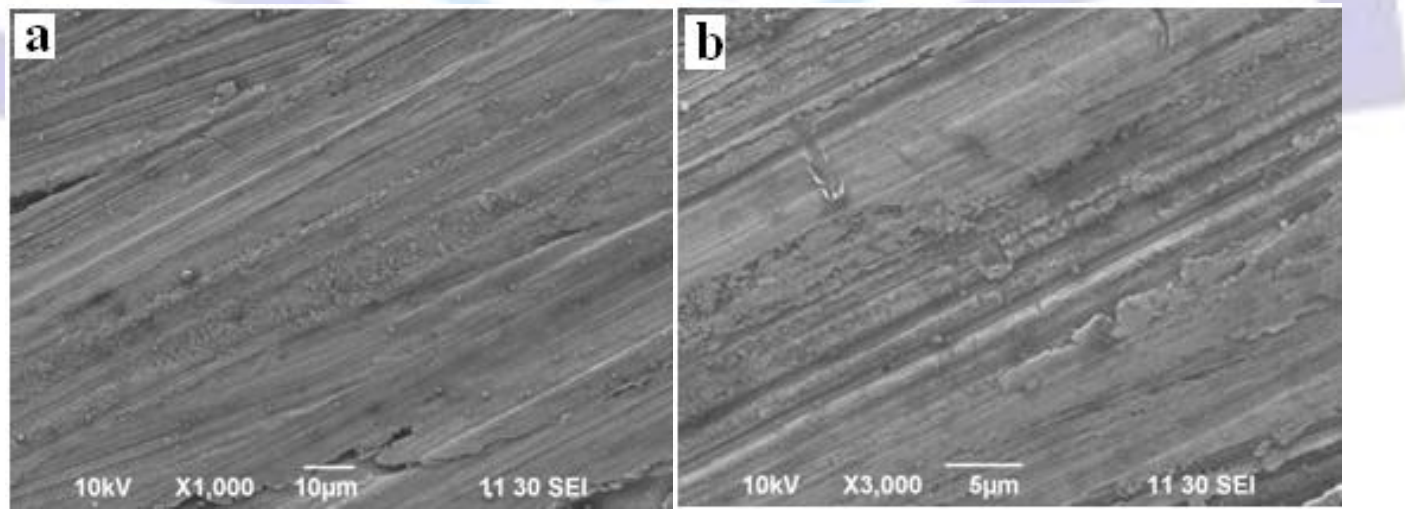

Figures 8 a \& b. SEM micrographs of polished Stainless steel (control) 

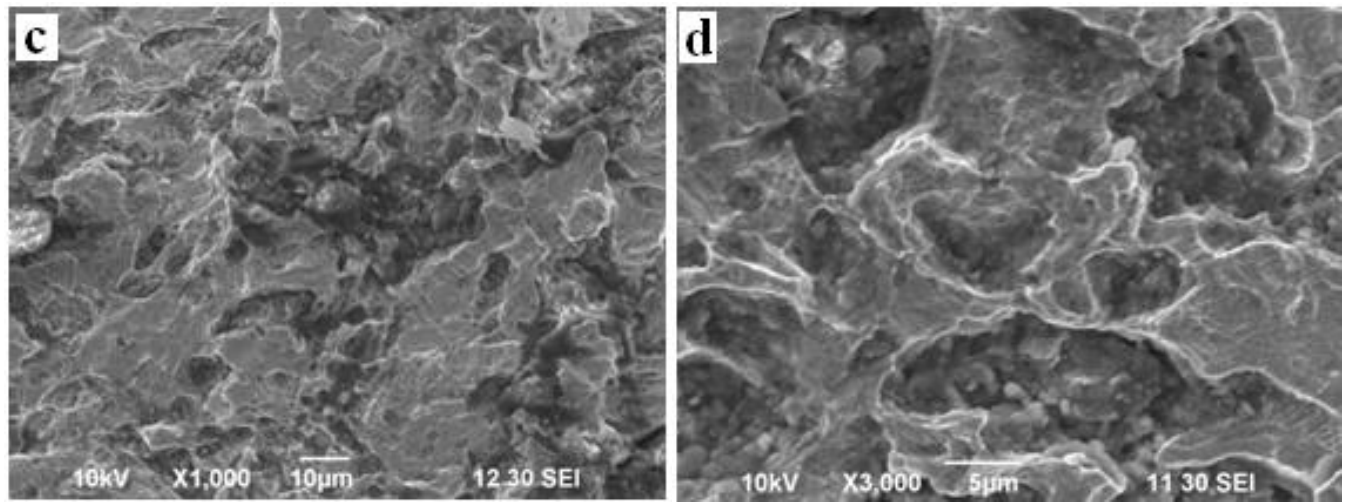

Figures $8 \mathrm{c} \& \mathrm{~d}$. SEM micrographs of Stainless steel in $0.5 \mathrm{M} \mathrm{H}_{2} \mathrm{SO}_{4}$ solution (Blank)
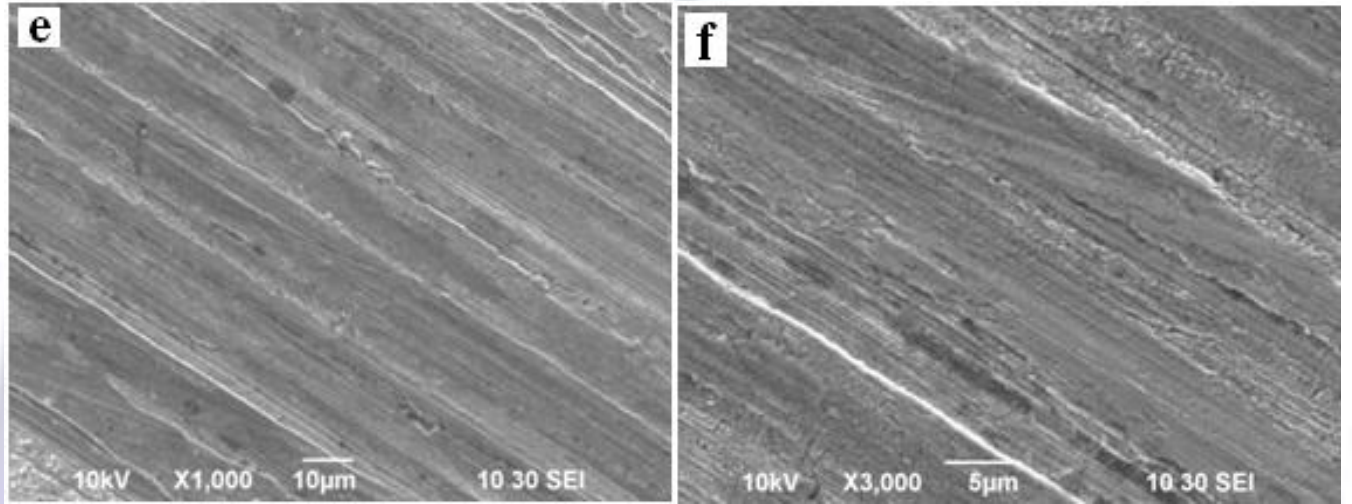

Figures 8 e \& f. SEM micrographs of Stainless steel in $0.5 \mathrm{M} \mathrm{H}_{2} \mathrm{SO}_{4}$ solution with 200 ppm DTPMP and 150 ppm TSC

Figures $8 \mathrm{c} \& \mathrm{~d}(\mathrm{x} 1000, \times 3000)$ show the SEM images of after immersion in $0.5 \mathrm{M} \mathrm{H}_{2} \mathrm{SO}_{4}$ solution (Blank) without DTPMP \& TSC showing the presence of small number of pits [51]. SEM investigations of the stainless steel surface data showed that, the surface was covered with a lower pit density. Figures 8 e \& $f(x 1000, x$ 3000) show the stainless steel surface protects after the addition of inhibitor concentration. It is observed that the protective film is formed on the surface of metal. These results are good agreement with the above discussion.

\subsection{Atomic Force Microascopy}

To establish whether inhibition is due to the formation of a film on the metal surface via adsorption, atomic force micrographs were taken. The two and three-dimensional AFM images are shown in (Fig. 9 a-f). As can be seen from (Fig. $9 \mathrm{c} \& \mathrm{f}$ ) there was much less damage on the surface of stainless steel with the DTPMP and TSC. The average roughness of polished stainless steel (Fig.9 a \& d) and stainless steel in $0.5 \mathrm{M} \mathrm{H}_{2} \mathrm{SO}_{4}$ without inhibitor (Fig.9 b \& e) was calculated. However in presence of 200 ppm of DTPMP and 150 ppm of TSC, average roughness was reduced is given in table 6.

Table 6. AFM data for stainless steel immersed in inhibited and uninhibited environments

\begin{tabular}{|c|c|c|c|}
\hline Samples & $\begin{array}{l}\text { Average Roughness } \\
\left(R_{a}\right) \mathrm{nm}\end{array}$ & $\begin{array}{l}\text { Root-mean-square } \\
\text { Roughness }\left(R_{q}\right) \mathrm{nm}\end{array}$ & $\begin{array}{l}\text { Maximum peak-to- } \\
\text { valley height }(P-V) \mathrm{nm}\end{array}$ \\
\hline $\begin{array}{l}\text { Polished stainless steel } \\
\text { (Control) }\end{array}$ & 16.83 & 25.24 & 157.75 \\
\hline \begin{tabular}{ll} 
Stainless & \multicolumn{2}{c}{ steel } \\
immersed in $0.5 \mathrm{M}$ \\
$\mathrm{H}_{2} \mathrm{SO}_{4}$ (Blank)
\end{tabular} & 63.28 & 73.08 & 295.29 \\
\hline $\begin{array}{l}\text { Stainless } \\
\text { immersed in } 0.5 \mathrm{M} \\
\mathrm{H}_{2} \mathrm{SO}_{4} \text { containing } \\
\text { DTPMP (200 ppm) and } \\
\text { TSC (150 ppm) }\end{array}$ & 27.00 & 37.43 & 175.51 \\
\hline
\end{tabular}



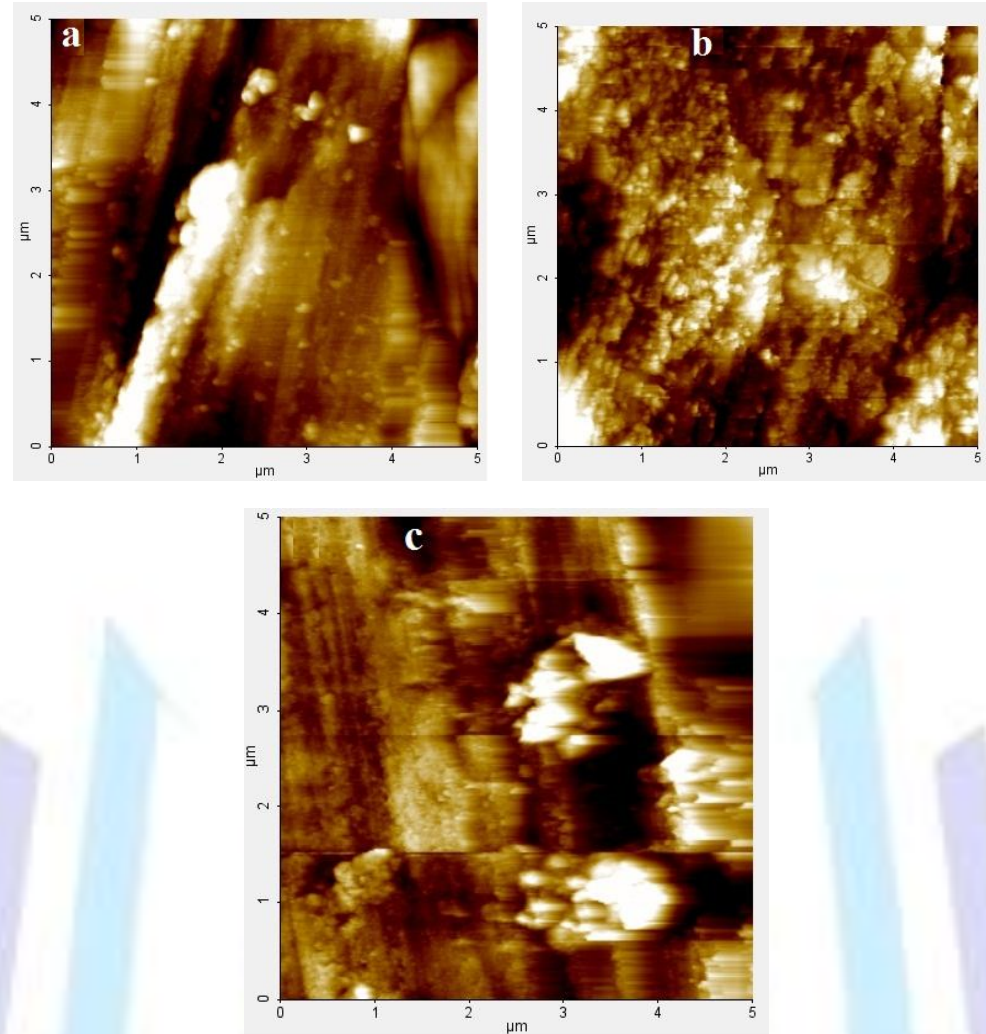

Fig. 9. 2D AFM images of stainless steel surface.

(a) Polished stainless steel (control)

(b) Stainless steel immersed in $0.5 \mathrm{M} \mathrm{H}_{2} \mathrm{SO}_{4}$ solution (blank)

(c) Stainless stee immersed in $0.5 \mathrm{M} \mathrm{H}_{2} \mathrm{SO}_{4}$ solution containing DTPMP (200 ppm) + TSC (150 ppm)
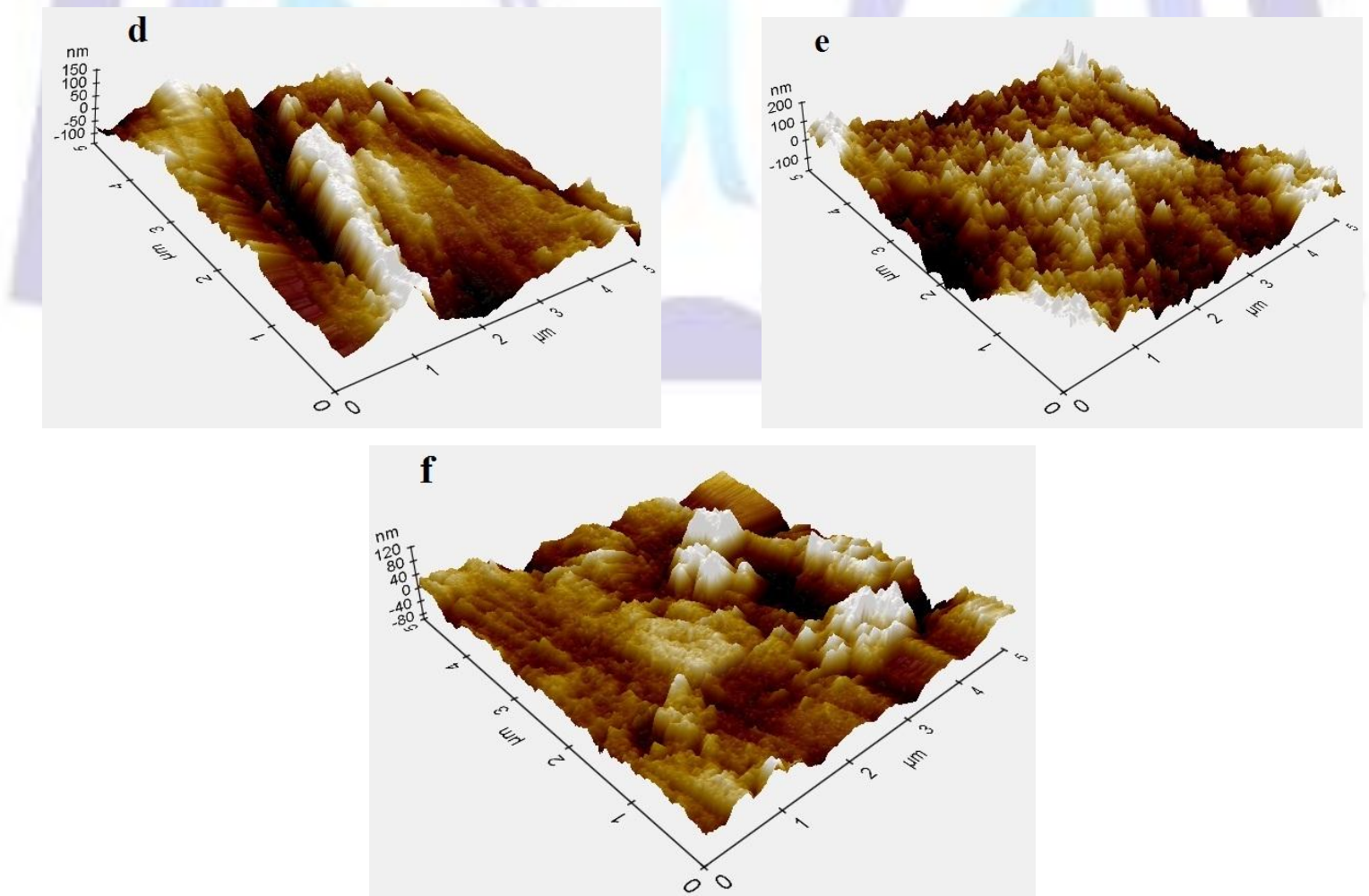
Fig. 9. 3D AFM images of stainless steel surface.

(d) Polished stainless steel (control)

(e) Stainless steel immersed in $0.5 \mathrm{M} \mathrm{H}_{2} \mathrm{SO}_{4}$ solution (blank)

(f) Stainless stee immersed in $0.5 \mathrm{M} \mathrm{H}_{2} \mathrm{SO}_{4}$ solution containing DTPMP (200 ppm) + TSC (150 ppm)

\section{CONCLUSIONS}

The following conclusions were made from the study

$>$ The DTPMP - TSC shows a significant corrosion inhibitors effect as evident from the results of weight loss studies.

$>$ Inhibition Efficiency of DTPMP - TSC was increased with increasing concentration while decreased with increasing temperature.

$>$ Polarization measurements suggested a mixed mode of action of the inhibitor.

$>$ Electrochemical impedance spectroscopy results confirmed the adsorption of inhibitor molecules onto stainless steel.

$>$ FTIR, SEM and AFM spectra results supported the surface film formation over the surface of stainless steel by inhibitor.

$>$ The adsorption of inhibitor on Stainless steel surface followed Langmuir adsorption isotherm.

$>$ The negative value of $\Delta \mathrm{G}_{\text {ads }}$ indicated that the adsorption is spontaneous and adsorption process is physisorption in $0.5 \mathrm{M} \mathrm{H}_{2} \mathrm{SO}_{4}$.

$>$ The negative value of $\Delta \mathrm{H}_{\text {ads }}$ indicated that the adsorption is exothermic process.

$>$ Energy of activation, enthalpies, entropies and heat of adsorption for the inhibition process of DTPMP - TSC were studied.

\section{REFERECES}

[1] Bala. H (1984) ElectrochimActa, 29, 119

[2] Ashassi-Sorkhabi H \& Eshaghi M, (2009) Mater Chem Phys, 111, 267.

[3] Dreyman E W, ASM Handbook, (1998) Corrosion, 13, 1221.

[4] Zhang Q B \& Hua Y X, (1881) ElectrochimActa, 54, 1881.

[5] Feng Y, Siow K S, Teo W K \& Hsieh A K, (1999) Corros sci, 41, 829.

[6] Ramero J M, Chavez C A, Martinez L \& Amaya M, (2002) Br Corros J, 37, 117.

[7] Sedriks A J \& Dudts $P,(2001)$ Corrosion, 57, 84.

[8] SathiyaA R, Muralidharan S, Velmurugan S \&Venkatachari G,(2008) Mater. Chem. Phys, 110, 269.

[9] Athar M, Ali H \&Quraishi M A,(2002) Br Corros J, 37 (2002) 155.

[10] Vuorinen E, Ngobeni P, Van Der Klashorst G H, Skinner W, De Wet E \& Ernst W S,(1994) Br Corros J, $29,120$.

[11] Bouklah. M, Ouassini. A, Hammouti. B, Elldrissi. A, (2005) Appl. Surf. Sci. 25,050.10.1016/j. apsusc. 2004.12..021

[12] Report No. SWCC (RDC) - 36, Saline Water Conversion Corporation, Saudia Arabia, March 1995.

[13] Kanouni. A.El, kertti. S, Srhiri. A, Bachir. K, (1996) Bull. Electrochem. 12 (9), 517.

[14] Cheng. Sh, Cheng. Sh, Liu. T, Chang. X, Yin. Y, (2007) Mater. Lett. 61, 3276.

[15] Ashassi-Sorkhabi. H, Shaabani. B, Seifzadeh. D, (2005) Electrochem. Acta 50, 3446

[16] Ebenso. E.E, (2003) Bull. Electrochem. 19, 209.

[17] Ferreira. S, Giancomelli. C, Giacomelli. F.C, Spinelli. A,(2004) Mater. Chem. phys. 83, 129-134

[18] Ashassi - SOrkkhabi. H, Majidi. M.R, Seyyedi. K, (2004) Appl. Surf. Sci. 225, 176-185.

[19] Riggs. O.L. Jr, C.C. Nathan (2 ${ }^{\text {nd }}$ Ed.), Corrosion inhibition, NACE, Houston, Tx, 1973, 11.

[20] Rajendran. S, Joany. R. M, and Apparao. B. V, (2002) . Indian journal of Chemical technology, 9, 197 -200.

[21] Hariharaputhran. R, Subramanian Alice Arul Anthony. A, Manisankar. P, Vasudevan. T, and Venkatakrishnalyer. S, (1999), Anti corrosion methods and mater, 46, 35-39. 
[22] Lowmunkhong. P, Ungthararak. D, Sutthivaiyakit. P, (2010), Corros. Sci. 52, 30-36

[23] Kalman. E, Varhegyi. B, Felhosi. I, Karman. F. H, Shaban. A, (1994) J. Electrochem. Soc. 141, 3357.

[24] Bonnel. A. Dabosi. F, Deslovis. C, Duprat. M, Keddam. M, Tribollet. B, (1983) J. Electrochem. Soc, $130,753$.

[25] El-Etre. A.Y., Abdallah. M., El-Tantaury, Z.E, (2004) J. Corros. Sci, 47 (2004) 385-395.

[26] Gunasekaran. G, Natarajan. R, Palaniswamy. N, (2001) Corrosion Science, 43, 1615 - 1626.

[27] Silverstein. R.M, Bassler. G.C, Moril. T, Spectrometric identification of organic compound, John wiley and sons, New York, 198.

[28] A.D. Cross, Introduction to practical infrared spectroscopy, Butter worths, scientific publication, London (1990) 73.

[29] Okafor. P.C, Ebenso. E.E, Ibok. U. J, Ekpe. U. J, and Ikpi. M.I, (2003) Trans. SAEST, 38, 91.

[30] Putilova. I.N, Barannik. V.P, and Balezin. S.S, Metallic corrosion inhibitors, Progress press, Oxford 30 (1960)

[31] Chandrasekaran.V, Kannan. K, and Natesan. M, (20050 Corrosion science and Tech, 4, 191-200.

[32] Subramanian. N, and Ramakrishnaiah. K, (1970) Indian. J. Tech, 8, 369.

[33] Bhajiwala. H.M, and Vashi. R.T, (2001) Bull Electrochem, 17, 441

[34] Ayssar Nahie, Ibrahim Abdel - Rahman and Mohamad Alfarouk, (2005) Bull. Electro chem. 21, 353-361.

[35] Solmaz. R, Kardas. G, Cuth. M.K, Yazici. B, Erbil. M, (2008) Electrochim Acta 53, 145

[36] Issa. R.M, El - Sonbati. A.Z, El-Bindary. A.A, and Kera. H.M, (2002) Eu. Poly. J. 38, 561.

[37] Cang. H, Fei. Z.H, Shi. W.Y, and Xu. Q, (2012) Int. J. Electrochem soc, 7, 10121

[38] Elchouri. M, Hajji. M.S, Salem. M, Kertit. S, (1996) J. Aride, R. Coudert. \& E. Essasi, Corrosion 103, 52.

[39] Savithri. B.V, \& Mayanna. S, (1996) Ind. J. Chem. Technol. 3, 226.

[40] Donahuce. F.M, \& Nobr. K, (1965) J. Electrochem Soc, 886, 112.

[41] Khamis. E, Bellucci. F, Latanision. R.M, \& El-Ashry. E.S.H, (1991) Corrosion 667, 47.

[42] De Souza. F.S, Spinelli. A, (2009) Corrosion Sci, 51, 642-649

[43] Kamal. C, Sethuraman. M.G, (2012) Arabian J. Chemistry 5, 155-161.

[44] Hackerman. N, (1962) Corrosion, 18, 332.

[45] Atya. B.G, El-Anadouuli. B.E, and El-nizamy. F.M, (1984) Corros. Sci, 24, 497.

[46] Cheng. X.L, Ma.ma. H.Y, Chens. H, Yu. R, Chen. X and Yao. Z.M, (1999) Corrosion. Sci, 41, 321.

[47] Boyayed. M, Rabaa. H, Srhiri. A, Saillard. J.Y, Bachir. A.B and Beuze. L.A, (1999) Corros. Sci, 41, 501.

[48] Behpour. M, Ghoreishi. S.M, Gandomi - Niasar. A, Salavati-Niasari. M, (2009) J. Mater. Sci, 44, $2444-2453$.

[49] Bockris. J.O.M and Swinkkels. A.J.D, (1964) J. Electrochem. Soc, 11, 736.

[50] Quraishi. M.A and Rana sardar, (2002) Bull. Electrochem. 18, 515.

[51] Rafaey. S.A.M, Taha. F, Abd El-Malak. A.M, (2004) applied surface science 263, 175. 